\title{
The "Chanson de Geste" and its Reception, Edited by Marianne J. Ailes, Elisabeth Cobby, Peter S. Noble
}

\section{Walter Meliga}

\section{(2) OpenEdition}

1 Journals

\section{Edizione digitale}

URL: http://journals.openedition.org/studifrancesi/1231

DOI: 10.4000/studifrancesi.1231

ISSN: 2421-5856

\section{Editore}

Rosenberg \& Sellier

\section{Edizione cartacea}

Data di pubblicazione: 1 décembre 2015

Paginazione: 561

ISSN: 0039-2944

\section{Notizia bibliografica digitale}

Walter Meliga, "The "Chanson de Geste" and its Reception, Edited by Marianne J. Ailes, Elisabeth Cobby, Peter S. Noble», Studi Francesi [Online], 177 (LIX | III) | 2015, online dal 01 décembre 2015, consultato il 06 janvier 2021. URL: http://journals.openedition.org/studifrancesi/1231 ; DOI: https://doi.org/ 10.4000/studifrancesi.1231

Questo documento è stato generato automaticamente il 6 janvier 2021.

\section{(c) (1)}

Studi Francesi è distribuita con Licenza Creative Commons Attribuzione - Non commerciale - Non opere derivate 4.0 Internazionale. 
The "Chanson de Geste" and its Reception, Edited by Marianne J. Ailes, Elisabeth Cobby, Peter S.
Noble

Walter Meliga 


\section{NOTIZIA}

The "Chanson de Geste" and its Reception. Essays presented to Philip E. Bennett by members of the Société Rencesvals, Edited by Marianne J. AILES, Elisabeth COBBY, Peter S. NOBLE, Edinburgh, Société Rencesvals British Branch, 2012 («British Rencesvals Publications», 5), pp. 166.

1 Mélanges dedicati all'epica francese, con ingressi di quella occitana e dei cantari italiani, in onore di uno dei più importanti medievisti inglesi. Dopo una breve presentazione della carriera di Philip Bennett con l'elenco delle sue pubblicazioni e una veloce introduzione alla raccolta, la miscellanea comprende gli interventi di: Marianne J. AILES, Giants and Outsize Warriors: Difference and Assimilation in the "Geste du roi"; Jane E. EVERSON, An Author and his Ghosts: Editorial Problems of a Posthumous First Edition (su Francesco Cieco e il suo Mambriano); Joël H. GRISWARD, Puzzle pour marionnettes: Aymeri de Narbonne et Carcas de Carcassonne; Bernard GUIDOT, De la chanson de geste au roman populaire: quelques aperçus fondés sur "Milles et Amys", réécriture d'Alfred Delvau; Françoise H.M. LE SAUX, Prowess, the Nine Worthies and the Hundred Years War: The Prologues to the "Chroniques" of Jean Froissart and Enguerrand de Monstrelet; Leslie ZARKER MORGAN, Flohart, Guinehart, Serpents and Feminie: "Carnaval au féminin" in the Guillaume d'Orange Cycle; Finn E. SINCLAIR, The Present of History: The "Canso de la Crozada"; François SUARD, Durendal: quelques avatars d'un objet mythique; Jean-Claude VALLECALLE, Destinée individuelle et destinée collective dans "Aquilon de Bavière". 